\title{
Early Infantile Epileptic Encephalopathy
} 19

National Cancer Institute

\section{Source}

National Cancer Institute. Early Infantile Epileptic Encephalopathy 19. NCI Thesaurus. Code C142802.

An autosomal dominant form of early infantile epileptic encephalopathy, caused by mutation(s) in the GABRA1 gene, encoding gamma-aminobutyric acid receptor subunit alpha-1. 